\title{
Relevance of the Executive Secretary Degree of the Autonomous University of Chiriqui 2017
}

\author{
Yesenia Martinez ${ }^{1} \&$ Luis Carlos Herrera ${ }^{2}$ \\ ${ }^{1}$ Autonomous University of Chiriqui (UNACHI), Panama; Center for Scientific Research of Social Sciences \\ (CENICS), Panama \\ 2 Santa Maria La Antigua University (USMA), Panama; National Research System (SNI), Panama; Center for \\ Scientific Research of Social Sciences (CENICS), Panama \\ Correspondence: Luis Carlos Herrera, Santa Maria La Antigua University (USMA), Panama; National Research \\ System (SNI), Panama; Center for Scientific Research of Social Sciences (CENICS), Panama. E-mail: \\ lherrera@usma.ac.pa
}

Received: August 28, 2019

Accepted: September 19, $2019 \quad$ Online Published: September 20, 2019

doi:10.5430/ijhe.v8n6p50

URL: https://doi.org/10.5430/ijhe.v8n6p50

\begin{abstract}
Higher education institutions must take into account the changing nature of the world of work. They must understand the capacities and competencies demanded by graduates of universities because in an unpredictable world, careers will undergo permanent changes and must respond to the changing needs of the labour market. In this article, we present the results of a study on whether the skills acquired by graduates of the Bachelor's Degree in Executive Secretariat of the Autonomous University of Chiriqui correspond to the needs demanded by the labour market. The research is based on a mixed methodology, which enables the integration of quantitative and qualitative approaches, providing a holistic view of the problem studied. The results of this study show that for employers, command of the English language and competence in the use of modern office equipment are essential for the performance of secretarial work.
\end{abstract}

Keywords: higher education, labour market, mixed research methods

\section{Introduction}

Modern universities must adapt their curricula to train professionals to meet the demands of the current labour market. The labour market is characterized by technological and scientific advances that require new competencies and soft skills as well as specialized knowledge that allows professionals to adapt with flexibility to new contexts and functions (Roldan Santamaria, 2005).

To identify success factors for future professionals, studies focused on university graduates and their evaluations of the quality and efficacy of university institutions (Marti Selva, Puertas Medina, \& Calafat Marzal, 2014). These studies have assumed that these variables can be measured based on the experiences of graduates in the first stages of their integration into the workforce.

This type of assessment considers success indicators, such as income, occupational level reached, and personal growth, that the graduates perceive themselves to have achieved (Cabrera, Weerts, \& Zulick, 2004.).

Other studies analyse the quality of higher education based on assessments of the competencies demonstrated by the graduates in their first job (Icarte \& Labate, 2016). The opinions of employers regarding the level of training and work performance have been typical sources of information in addition to the graduates' own evaluations of the competencies achieved throughout their training (Rubio, 1998).

Graduates' self-assessment of their competencies reveals that learning contexts and teaching methodologies play an important role in acquiring job skills (Cabrera Lanzo, Lopez, \& Portillo Vidiella, Graduates' competences and assessment from their employers' perspective, 2016). Graduates' self-evaluations of their university education, depending on the public or private nature of the universities, show that graduates from private universities score themselves higher than do graduates of public universities (Sanchez-Gelabert \& Navarro-Cendejas, 2016).

The perception that the training received is related to graduates' job placement expectations indicates a relationship between satisfaction with the training programme and the subsequent professional success achieved, or job satisfaction; 
thus, a well-organized programme with good teaching content and an emphasis on practical work contributes to job satisfaction (Ana, Gomez, \& March., 2013).

Graduates' assessments of the higher education they received have been part of large-scale surveys conducted in different European countries with the aim of assessing graduates' employment situation and the role of their competencies in the different phases of their professional career (Cabrera, Weerts, \& Zulick, 2004.).

International studies show that university institutions are concerned about the high rates of unemployment recorded and have thus begun conducting surveys of graduates (Gomez Rodriguez, Ortiz Muñoz, \& Gonzalez Fernandez, 2017) (Sole-Moro, Sanchez-Torres, Arroyo-Cañada, \& Argila-Irurita, 2018) (Jaramillo, Pineda, \& Ortiz Correa, Estudios sobre egresados La experiencia de la Universidad EAFIT, 2006). In principle, these studies have focused more on the graduates' labour situation than on the training received; however, this second topic has gradually gained importance (Mora \& Vidal, 2001) and is present in almost all studies on labour integration generated by universities. With attention that in the Latin American region we share these challenges (Herrera, 2017).

Regarding the labour market, Hernandez (2004) describes the main characteristics of professionals in Mexico during the 1990s, examining various aspects that influence access to the labour market-including demographic trends, characteristics of graduates of the higher education system, and structure and analysis of the balance between the supply and demand of professionals - as well as the effects of these factors on the remuneration of professionals.

To enter the labour market in Panama, graduates in the executive secretary field encounter the same difficulties as other professionals, and those who manage to join the workforce are often placed in areas that are unsuited to them or must submit to undesirable working conditions (Rodriguez Solera, 2003). Among these conditions are short-term contracts, excessive performance pressure, low salaries, and the threat of personnel cuts.

The Autonomous University of Chiriqui (UNACHI) of Panama was created by Law No. 26 of August 30, 1994, and modified by Law No. 4 of January 16, 2006. UNACHI assumed the challenge of being the best university of the interior of the Republic of Panama and adopted the executive secretary degree as a career path, offering the degree for the first time in 1976 at the Chiriqui Regional University Centre.

\section{General Status of the Problem}

The graduates of the executive secretary programme of the UNACHI must have psychomotor skills and abilities in the techniques of stenography, archival science, operation of different office equipment, and drafting and professional management of documents and must demonstrate values and ethical principles in their academic, work, and social activities.

Panamanian entrepreneurs today have more demands regarding the profile of employees and how they integrate into a job. The skills that in the past allowed an individual to remain in a position are now insufficient (Valencia, Las Competencias Laborales: ¿La estrategia laboral para la competitividad de las organizaciones?, 2005); it is necessary to have technological competencies and to be familiar with other forms of organization, management, and innovation in processes and in interaction between people.

Panama is a country where the commerce and services sector is the main source of income; market demand and universities' respective academic offerings are closely linked. However, despite the increase in companies, there has been no increase in the demand for professionals with an executive secretary degree. This study raises the following question: What is the employers' level of satisfaction with the skills acquired by holders of the executive secretary degree from the UNACHI in response to the needs of the labour market?

\section{Methods}

This research implements a sequential mixed-methods design, a variant of sequential transformative design (Hernandez Sampieri, Fernandez Collado, \& Baptista Lucio, 2014). The essence of the sequential design is based on stages in which data are collected (quantitative or qualitative); then, in a series of subsequent phases, the other methods are used to process the information.

Selection of cases:

The companies from the province of Chiriqui that met the following requirements were chosen:

1. Belong to the commerce and services sector.

2. Have been in the market for more than 10 years.

3. Have more than 10 employees and, among them, more than two secretaries working who are graduates of UNACHI 
A total of 15 companies met the criteria.

Instruments

In this research, instruments proposed by the curricular directorate of UNACHI were used; these instruments were validated by the university and used in the self-assessment process for degree guidance.

\section{Results}

In Chiriqui Province, there is stable economic growth, an important indicator in the business market: by 2015 , this province had approximately 17,310 companies registered (Note 1 ).

Table 1 shows the statistics for degree enrolment where income in recent years has been maintained.

Table 1. Enrolment by degree and year at the Autonomous University of Chiriqui

\begin{tabular}{ccccccccccc}
\hline Faculty of Publicity & 2005 & 2006 & 2007 & 2008 & 2009 & 2010 & 2011 & 2012 & 2013 & 2014 \\
\hline Executive Secretary Technician & 0 & 31 & 63 & 0 & 0 & 0 & 0 & 0 & 0 & 0 \\
Degree: Executive Secretary (campus) & 105 & 48 & 9 & 26 & 100 & 87 & 89 & 73 & 74 & 69 \\
Degree: Administrative Executive & 0 & 2 & 37 & 91 & 0 & 18 & 13 & 36 & 29 & 65 \\
Secretary (Baru) & & & & & & & & & & \\
\hline
\end{tabular}

Source: Planning Department. Autonomous University of Chiriqui 2015.

The level of satisfaction of employers regarding graduates of the School of Executive Secretariat of UNACHI revealed quite positive results: $73 \%$ said they were largely satisfied with graduates' competencies in the domain of theoretical knowledge; in the field of practical application of knowledge, $80 \%$ of respondents believed that graduates meet the requirements of the company. With respect to UNACHI graduates' ability to manage and operate new technologies, $40 \%$ of employers felt that the graduates largely effectively manage the new technologies; $46.67 \%$ of employers considered the graduates to have teamwork skills; $60 \%$ considered the graduates of the executive secretariat programme to have effective oral and written communication skills; and $40 \%$ of employers believed that they largely meet the requirements to make diagnoses and solve problems. In terms of knowledge of professional methods and techniques, $60 \%$ indicated that they were very satisfied. In relation to leadership and responsibility, $87 \%$ of employers reported being fully satisfied. When asked about the fulfilment of the demands of the work, 53\% of employers felt that the graduates meet the requirements to a large extent. Another element addressed was creativity and proactivity, where $60 \%$ of employers indicated that they were very satisfied. In terms of administrative performance, $80 \%$ of employers believed that graduates largely meet the requirements. Finally, employers were asked whether, in general terms, they are satisfied with graduates of the School of Executive Secretariat of UNACHI in relation to the demands of the labour market, and $87 \%$ said they were very satisfied.

The results presented so far regarding the opinion of employers when hiring a graduate of UNACHI should be compared with similar results regarding graduates of other universities in the province of Chiriqui. A total of $67 \%$ of employers reported that UNACHI graduates are better prepared for the labour market than are graduates from other universities, and $33 \%$ considered otherwise.

To complement the quantitative information presented, the results of the qualitative interviews conducted with employers and graduates are presented.

Open-ended interviews with employers and graduates on demands and aspirations

Aspects that the graduates prioritized:

1. Claim curricula to be obsolete, overly focused on theory and providing real training in only three or four subjects. There is a widespread complaint regarding the lack of practical subjects.

2. Professional training and private universities end up presenting employers with a better image than the public universities in regard to the practical value of students' studies and in the transmission of values of control and discipline.

3. It is perceived that companies require language skills and, in some sectors, discipline and that graduates work for little money.

4. Graduates believe that their professional performance does not respond to the expectations created. 


\section{Aspects that employers prioritized}

1. Rapprochement between the university and society in a context of the knowledge society is essential; the university is perceived as a self-absorbed institution that needs to be open to specific and necessary knowledge for current work requirements.

2. Competencies required: curricula focused on training more than on theoretical education are demanded in addition to more internships.

3. Secretaries with advanced knowledge of the English language with good discipline and facility in personal relationships are required.

4. Languages, and particularly English, continue to be seen as a great deficiency. However, user-level computing is no longer considered a serious obstacle or problem.

\section{Semi-structured interviews with employers.}

1. What are the main strengths, in your opinion, of UNACHI graduates?
a) Discipline
b) Prompt attention
c) Punctuality
d) Organization

2. What limitations have you observed in the performance of the graduates of the degree programme?
a) Proficiency in a second language
b) Conflict resolution
c) Computer systems
d) Use of modern office equipment

3. What criteria do you use to select suitable professionals to occupy the position of executive secretary?
a) Writing
b) Working as a team
c) Organization
d) Knowledge and management of offices
e) Proficiency in English

4. What competencies should be prioritized in the executive secretary training for the graduate to perform effective and efficient work in your company?
a) Writing
b) Spelling
c) English at an advanced level
d) Use of modern office equipment
e) Working under pressure
f) Working as a team
g) Conflict resolution

Semi-structured interviews with graduates:

1. Note the essential aspects that, in your opinion, the job profile of an executive administrative secretary should include.
a) Proficiency in English
b) Management of modern office equipment
c) Internships or contact with companies during their degree
d) Accounting 
e) Practical decision making

2. Note the important aspects that, in your opinion, the job profile of an executive administrative secretary should include.

a) Proficiency in the English language

b) Management of modern office equipment

c) Internships or contact with companies during their degree

d) Only business students should be accepted

e) School must have a specialized laboratory with modern equipment

3. Note any aspects of convenience that, in your opinion, the job profile of an executive secretary should include.

a) Degrees should be offered during evening hours for students' convenience

b) Programme should be short

c) More competitive with the market and better schedules

4. What are the main strengths that, in your opinion, provided you with your professional training for job performance?
a) Working as a team
b) Responsibility
c) Discipline
d) Office attire and correct job performance
e) Office organization
f) Filing
g) Typing

5. What are the main weaknesses in professional training that have limited your performance in the workplace?
a) Knowledge of English
b) New technologies
c) Little practice in real life
d) Contact with companies
e) Classes only in the morning, which makes it difficult for people who work to earn this degree

6. What aspects do you consider your greatest strengths in the exercise of your position?
a) Use of the computer
b) Writing with precision and clarity
c) Attention to the public
d) Correct file use
e) Telephone support

7. Tell us about your experience in the process of entering the labour market.

a) Employers administer writing tests

b) Spelling is emphasized

c) Attire and how to behave are considered important

d) Similar competence to graduates from other professions such as human resources, business, public, and advertising

8. Do you think that the university provided the necessary skills to fulfil the functions of the position?

a) In theoretical knowledge, yes, but we lacked more practical exercises or contact with companies

b) We did not go to companies, only those that perform professional internships at the end of the degree 
9. What aspects were most difficult to address in the development of your work?
a) Making some decisions
b) Telephone support in another language
c) Use of some new equipment
d) Use of fax, photocopying equipment, and others

10. What are the aspects that influenced your being hired, e.g., permanence, continuity, promotion, layoff, among others?
a) Performance
b) Organization
c) Dealing with customers
d) Writing and organization of files and correspondence
e) Image and personal appearance

\section{Conclusions}

The results of the research provide UNACHI with the necessary information to continue improving the quality of their graduates.

Companies need professionals who have mastery of the English language, writing, and spelling, technology management, soft skills, attitudes, aptitudes, and abilities pertinent to the performance of secretarial work in a modern company.

The executive secretary curricula at UNACHI must be updated, with an emphasis on bilingual and computerized training and technology management, to meet the expectations of the student population and the labour market.

It is necessary to adapt the curriculum to produce a comprehensive professional graduate so that there is no discordance between higher education and the needs of employers and graduates.

Although employers in the province of Chiriqui prefer UNACHI graduates over graduates from other universities, it is important to maintain an up-to-date curriculum that trains executive secretaries at a high academic and professional level.

\section{Acknowledgments}

Special thanks to Special thanks to Ph.D. Heriberto Franco, Professor of UNACHI, for his comments. To the National Research System of Panama (SNI). To the Autonomous University of Chiriqui (UNACHI) and finally to the Santa Maria La Antigua University (USMA).

\section{References}

Ana, M. M., Gomez, B. R., \& March., J. H. (Abril de 2013). Mismatches between higher education and the labour market in Engineering Sciences: the employers' point of view from the region of Madrid. Revista de Educación, 244-267. https://doi.org/10-4438/1988-592X-RE-2011-360-110

Cabrera Lanzo, N., Lopez, M., \& Portillo Vidiella, M. (2016). Graduates' competences and assessment from their $\begin{array}{llll}\text { employers' } & \text { perspective. } & \text { Estudios } & \text { Pedagogicos, }\end{array}$ https://doi.org/10.4067/S0718-07052016000400004

Cabrera, Weerts, \& Zulick. (2004.). Encuesta a egresados: Tres fundametnos conceptuales en el seguimiento de egresados universitarios. En J. V. García, Métodos de análisis de la inserción laboral de los universitarios (págs. 55-89). Madrid: Ministerio de Educación, Cultura y Deporte. Obtenido de http://sid.usal.es/idocs/f8/fdo7238/estudio.pdf

Gomez Rodriguez, H., Ortiz Muñoz, E. P., \& Gonzalez Fernandez, M. O. (2017). The study of graduates for the continuous improvement of the universities: Case study of Computer Engineering. Revista Iberoamericana para la Investigación y el Desarrollo Educativo, 1-23. https://doi.org/10.23913/ride.v7i14.279

Hernandez Sampieri, R., Fernandez Collado, C., \& Baptista Lucio, P. (2014). Metodología de la Investigación. Mexico D.F.: McGraw-Hill.

Herrera, L. C. (2017). Process of Integration of Latin America and The Caribbean. Revista de Ciencias Sociales(158), 167-183. https://doi.org/10.15517/rcs.v0i158.32785 
Icarte, G., \& Labate, H. (2016). Methodology for Reviewing and Updating a Curriculum Design of a University Career Incorporating the Concept of Competency-based Learning. Formación Universitaria, 3-16. https://doi.org/10.4067/S0718-50062016000200002

Jaramillo, A., Pineda, A., \& Ortiz Correa, J. (2006). Estudios sobre egresados La experiencia de la Universidad EAFIT. Revista Universidad EAFIT, 111-124. Retrieved from http://publicaciones.eafit.edu.co/index.php/revista-universidad-eafit/article/view/818

Marti Selva, L., Puertas Medina, R., \& Calafat Marzal, C. (2014). Qualityand efficiency of Spanish Public. Revista de Estudios Regionales(99), 135-154. Retrieved from http://www.revistaestudiosregionales.com/contenido/ver/id/116

Mora, J.-G., \& Vidal, J. (2001). Changes in Spanish Universities: Improvements and Unsolved Conflicts. Planning for Higher Education Journal, 29(2). Retrieved from https://www.scup.org/resource/changes-in-spanish-universities-improvements-and-unsolved-conflicts/

Rodriguez Solera, C. R. (2003). La inserción laboral de egresados de la educación superior en el estado de Hidalgo. Revista de la Educación Superior, 32(127), 7-22. Retrieved from http://publicaciones.anuies.mx/revista/127/2/1/es/la-insercion-laboral-de-egresados-de-la-educacion-superior-en -el

Roldan Santamaria, L. M. (2005). Elementos para evaluar planes de estudio en la educación superior. Revista Educacion, 29(1), 111-123. https://doi.org/10.15517/REVEDU.V29I1.2040

Rubio, J. (1998). Esquema básico para estudios de egresados. Mexico: Asociación Nacional de Universidades e Instituciones de Educación Superior.

Sanchez-Gelabert, A., \& Navarro-Cendejas, J. (2016). Graduates"e assessment of their university education. An approach from their current employment status. Revista Complutense de Educación, 27(2), 669-688. https://doi.org/10.5209/rev_RCED.2016.v27.n2.47007

Sole-Moro, M. L., Sanchez-Torres, J., Arroyo-Cañada, F., \& Argila-Irurita, A. (2018). University graduates and placement: an approach to the Latin American and Spanish panorama. Revista CEA, 4(8), 67-74. https://doi.org/10.22430/24223182.1048

Valencia, M. (2005). Las Competencias Laborales: ¿La estrategia laboral para la competitividad de las organizaciones? Estudios Gerenciales (EG)(96), 31-55. Retrieved from https://www.icesi.edu.co/revistas/index.php/estudios_gerenciales/article/view/170

\section{Note}

Note 1. P1 According to data from the Ministry of Commerce and Industry of Chiriqui Province. 